\title{
WOMEN-LED FILMS: DIFFERENT FEMALE REPRESENTATIONS IN POPULAR CINEMAS.
}

\author{
FEI JIUN KIK
}

\begin{abstract}
:
This is a comparative study to look into cinematic feminism between English-speaking blockbuster and non-blockbuster films that screening from 2012 to 2015 . This study will choose films that led by female character(s) and to explore, compare, and justify the feminism qualities that reflected through the female characters and storylines. In this study, six female-led films are selected: The Hunger Games, Mad Max: The Fury Road, Cinderella, Gone Girl, Brooklyn, and Carol. This study assumes that modern high budget productions are portraying feminism conventionally through unrealistic characters and masculine domination stories; while the non-blockbuster productions are portraying feminism progressively through reflective characters and self-determination stories. Blockbuster films' actresses are commonly created as recognisable female superheroes with strong masculine traits but living in a men-ruled world, or princesses that living in fairy tales. The cinematic feminism is superficial and ambiguous in blockbuster commercial films. Hence, non-blockbuster films' actresses are characterised with conservative and realistic images but given more chances to deal with alternatives, decisions, and progressions throughout the development of the story. Non-blockbuster films' characters and stories are less emphasizing on masculine feminism but more focusing on subtle yet significant feminism expressions. To achieve the objectives and hypotheses, this paper uses two methods - quantitative method with a designed coding sheet in content analysis; and a qualitative method with film reviews for textual analysis. These two methods are expected to test out and evaluate the cinematic feminism through on-screen characters' gender representations and the storyline's interpretations in selected films.
\end{abstract}

\section{Keywords:}

films, feminism, cinema, blockbuster, mainstream, art-house, productions, gender, portrayals.

JEL Classification: L23, L82, J16

\section{Authors:}

FEI JIUN KIK, Tunku Abdul Rahman University College, Malaysia, Email: kikfj@tarc.edu.my

\section{Citation:}

FEI JIUN KIK (2019). Women-Led Films: Different Female Representations in Popular Cinemas.. International Journal of Social Sciences, Vol. VIII(2), pp. 88-107., 10.20472/SS.2019.8.2.006 


\section{Introduction}

Captain Marvel (2019), Frozen 2 (2019), Tomb Raider (2018), Ocean's 8 (2018), Wonder Woman (2017), Lucy (2014), Divergent (2014), experienced tremendous commercial success in the film industry; and the leads of these blockbuster films created revolutionary changes and constructed new wave of on-screen feminism in popular cinemas. These top-grossing films' female protagonists broke free from the traditional stereotypical identities of victims, wives and femme fatales; they performed with higher athletics abilities, better fighting skills, and greater leadership.

The new-fangled female heroes obtained the international acceptance and substantial grossing, at the same time, these female heroes brought a refreshed image of cinematic feminism to global spectators. However, under the spotlight of popular leads on commercial screens, lesser attention is given to art house or non-popular female-led films. The films such as Destroyer (2018), Eighth Grade (2018), Room (2015), 45 Years (2015), Joy (2015), Still Alice (2014), Blue Jasmine (2013) that have no glitzy female heroes, world saviours, or pretty princesses to fascinate mass audience; these films conveyed the feminist potentials and inspirations through social realistic stories.

\section{Research Problem / Research Question / Research Hypotheses}

This paper focuses on three research problems: (1) What are the feminist qualities that presented in mainstream blockbuster and in art house films? What are the differences in between? (2) In what extent do the recent female-leading films reflect on-screen feminism through characters and storylines? (3) How cinematic gender progression connects to contemporary society?

To answer the above-mentioned questions, the objectives of this paper are to (1) Explore the cinematic feminism in mainstream blockbuster films and non-blockbuster art house films; (2) Compare feminist qualities through representations of character and interpretations of storyline; (3) Justify the reflections of reality in between mainstream blockbuster films and non-blockbuster art house films.

This paper assumes that: (1) Mainstream blockbuster films and non-blockbuster art house films will reveal different interpretations of feminism; (2) Mainstream blockbuster films emphasize on an unrealistic character such as heroin or princess by a male-manipulated and patriarchal story; comparatively, non-blockbuster art house films emphasize on an insightful character with a realistic story.

\section{$2 \quad$ Literature Reviews}

\section{Types of Feminist}

By referring the conventional types of feminism such liberal feminism, which argues that "society has a false belief that women are by nature less intellectually and physically capable than men" (Tong, 2009), or feminism should work with the social structure without much physical and mental withdrawal from the mainstream community. Applying into films, the female characters are expected to have equal involvement in the roles and stories development. On the other side, cultural feminism commends the positive aspects of what is seen as the female character or feminine personality. Hence, cultural feminism is a theory praises the positive aspects of women; 
focuses on the difference between man and woman from the external and internal perspectives such as biology, physical, personality, and behaviour. Cultural feminism appreciates and embraces the femininity and natural traits of women such a kind and gentle and believes that could create a better world. "Cultural feminist approach to acknowledge and celebrate those qualities that are associated with femininity. We argue that by recognising and valuing feminine qualities, cultural feminism can help reform the existing (male-dominated) structures" (Syed, 2008).

\section{The Bechdel Test and Mako Mori Test}

The Bechdel Test (also known as Bechdel-Wallace Test) is inspired by a cartoonist Alison Bechdel and her strip comic The Rule in 1985, which become a general guideline to evaluate feminism in films and to justify cinematic gender bias with simple three criteria - the film must have at least two female characters with names; these two female characters must talk to each other; and these two female characters must talk about something other than a man. Bechdel Test commonly and famously becomes a popular method for many international cinemas to capture the female representations as this test is quick and easy to assess sexism in movies. All these years, this test is constantly supported and challenged from different perspectives.

In 2013, when Pacific Rim released, it failed the test just because the movie has only one female character. A Tumblr user, Chaila found the insufficiency of the Bechtel Test through Pacific Rim and she reformed the test with a new formula and alternated criteria then named it as Mako Mori Test. In Mako Mori Test, a feminism movie: 1. must have at least one female character with a name; 2. at least one female character has her own narrative arc; 3 . the female character's narrative arc does not support a man's story in the film. For recent years, both the Bechdel Test and Mako Mori Test are used as a general tool to measure the feminism in modern cinemas.

\section{Visual Pleasure and Cinema Narrative}

Laura Mulvey's in her paper that published in 1975, Visual pleasure and cinema narrative, argued that Hollywood cinema objectified and presented women into fascinated images to provide a pleasurable visual experience for men. In her study suggested that the onset of gender stereotypes in classical and mainstream Hollywood cinemas could be understood from the perspective of heterosexual male viewers and their voyeuristic pleasure gained from female castrated images. "She argued that mainstream cinema is constructed for a male gaze, catering to male fantasies and pleasures. Uncovering the voyeuristic and fetishistic responses of male spectators to images of women," (Chaudhuri, 2006). The gaze could be briefly explained in three ways: how men look at women; how women look at themselves; and how women look at other women. The result of the gaze produced two common reactions among viewers - voyeuristic scopophilia, which refers the pleasure linked to sexual attraction, the desire to see the erotic, forbidden; and narcissistic scopophilia, which refers satisfaction reflected (usually) with the male, who is the pivot of the film, its hero, while a female is a threat. Visual pleasure and cinema narrative is still a powerful work to define, interpret and evaluate feminism in popular films.

\section{Methodology}

Six English-speaking popular female-leading films from 2012 to 2015 are selected and categorised into two groups [figure 1]: Group A - three Hollywood mainstream films and Group B 
- three non-blockbuster films. Group A of films produced with a high budget, performed top grossing in the box office, targeted for the mass international market. This group of films is popularly advertised before/during the showing, also focused on homogenised genres such as action, thriller, and romance in global cinemas. Group B of films are mostly art house or independent films that produced with a low budget, targeted to specific viewers and expressed content value, these films are neither heroines nor princess films. In this study, films in Group A are The Hunger Games (2012), Mad Max: The Fury Road (2015) and Cinderella (2015). In Group B, films selected are Gone Girl (2014), Brooklyn (2015) and Carol (2015).

This paper holds two methods/studies. Each lead character's portrayals, storyline's interpretations, and realistic reflections will be examined and compared in study 1 and study 2, and each contains a quantitative method and qualitative method respectively. Study $1-$ content analysis, six selected films will be tested through a coding sheet with 15 test points. Study $2-$ textual analysis, six selected films will be analysed through film reviews. Study 1 and 2 are developed and conducted based on the five fundamental criteria as the following:

1. Identity of the female protagonist is recognisable, and her name is commonly addressed and easy to recall by most viewers; objectification towards her image is not apparently observed in the film.

2. The ability of problem-solving and decision making of the female protagonist is obviously witnessed in the film; she makes her own decisions to solve her problems.

3. Choices and options are provided with the free will of the female protagonist, and female protagonist neither is victimised nor punished based on her decisions. Eventually, she is happy with her made choice.

4. Efforts and courage are showed by/in female protagonist towards unequal treatments that against her.

5. Feelings and thoughts of the female protagonist are being expressed in the film.

The five criteria above are the core ideas to measure cinematic feminism in this paper. Inspired by the Bechdel Test and Mako Mori Test, this paper designed a coding sheet for study 1 [figure 2] that contained 15 specific test points that developed from the above-mentioned five fundamental criteria, and this coding sheet will be used to examine cinematic feminism in the selected femaleleading films. Films that meet more criteria will be coded as the films that reflected higher feminism.

This coding sheet will evaluate feminism from the two major perspectives - characters and storylines. In the coding sheet, Part $A$ (point $A 1$ to $A 10$ ) is designed to measure the lead character's gender representations including her identity \& image, level of freedom \& efforts given, the ability of decision-making, the ability of problem-solving, and freedom to express. Part B (point B1 to B5) is designed to measure the storyline and gender interpretations including plots/scenes that indicating specific narrative meanings and also the story's connection towards realistic society. The result is summarised in figure 3.

Also, in study 2, a textual analysis will be conducted to analyse the six selected films from the perspectives of characters and storylines through film reviews. 
Figure 1: SIX female-leading films from the years 2012 to 2015.

\begin{tabular}{|l|l|l|l|l|l|}
\hline Group A Film & Year & Lead characters & Group B Film & Year & Lead characters \\
\hline The Hunger Games & 2012 & Katniss Everdeen & Gone Girl & 2014 & Amy Dunne \\
\hline Mad Max: Fury Road & 2015 & Imperator Furiosa & Brooklyn & 2015 & Eilis Lacey \\
\hline Cinderella & 2015 & Cinderella & Carol & 2015 & Carol Aird \\
\hline
\end{tabular}

Source: Own developed coding sheet.

Figure 2: Coding sheet to measure cinematic feminism from the perspectives of characters and storylines.

\begin{tabular}{|l|}
\hline Part $\boldsymbol{A}$ \\
\hline Identity \& image: \\
\hline A1. The female protagonist is addressed with her name commonly, and her name is easy to recall. \\
\hline A2. The female protagonist is not objectified (as a romance target, sexual object, materialism, victim, etc.). \\
\hline Freedom \& effort: \\
\hline A3. The female protagonist is having the freedom and choice to decide her own life. \\
\hline A4. The female protagonist is making an effort to change her life to better. \\
\hline A5. The female protagonist is able to reject unequal treatments and avoid being a victim. \\
\hline Decision making: \\
\hline A6. The female protagonist is making at least one important decision in the film. \\
\hline A7. The decision is not causing others or herself to become a victim. \\
\hline Problem-solving: \\
\hline A8. The female protagonist is able to solve problems. \\
\hline A9. The female protagonist is not depending on others to solve her problems. \\
\hline Thinking expressing: \\
\hline A10. The female protagonist is expressing her thinking or feeling, at least once. \\
\hline Part B \\
\hline Reflection of reality: \\
\hline B1. The storyline and the experience of the female protagonist are possible for reality. \\
\hline Story: \\
\hline B2. The female protagonist is happy at the end. \\
\hline B3. The female protagonist is becoming a better person in the end. \\
\hline $\begin{array}{l}\text { B4. The story is not showing that the female protagonist's destiny is more or les s depending on the decision } \\
\text { of another man. }\end{array}$ \\
\hline B5. Overall, the story is not a male-domination story. \\
\hline Sorce: Own developed coding sheet. \\
\hline
\end{tabular}

Source: Own developed coding sheet.

Figure 3: Result for Cinematic Feminism Measurement.

\begin{tabular}{|l|l|l|l|l|l|l|}
\hline Films & $\begin{array}{l}\text { Feminist } \\
\text { Criteria } \\
{[\text { Character }]}\end{array}$ & $\begin{array}{l}\% \text { Feminist } \\
\text { Criteria } \\
\text { [Character }]\end{array}$ & $\begin{array}{l}\text { Feminist } \\
\text { Criteria } \\
{[\text { Storyline }]}\end{array}$ & $\begin{array}{l}\text { \% Feminist } \\
\text { Criteria } \\
\text { [Storyline] }]\end{array}$ & $\begin{array}{l}\text { Feminist } \\
\text { Criteria } \\
{[\text { Total }]}\end{array}$ & $\begin{array}{l}\text { Total } \\
\text { Percentage } \\
\text { on } \\
\text { Cinematic }\end{array}$ \\
\hline
\end{tabular}




\begin{tabular}{|l|l|l|l|l|l|l|}
\hline & & & & & & Feminism \\
\hline $\begin{array}{l}\text { The Hunger } \\
\text { Games }\end{array}$ & $6 / 10$ & $60 \%$ & $1 / 5$ & $20 \%$ & $7 / 15$ & $47 \%$ \\
\hline $\begin{array}{l}\text { Mad Max: } \\
\text { The Fury } \\
\text { Road }\end{array}$ & $7 / 10$ & $70 \%$ & $2 / 5$ & $40 \%$ & $9 / 15$ & $60 \%$ \\
\hline Cinderella & $2 / 10$ & $20 \%$ & $2 / 5$ & $40 \%$ & $4 / 15$ & $26 \%$ \\
\hline Gone Girl & $10 / 10$ & $100 \%$ & $3 / 5$ & $60 \%$ & $13 / 15$ & $87 \%$ \\
\hline Brooklyn & $10 / 10$ & $100 \%$ & $5 / 5$ & $100 \%$ & $15 / 15$ & $100 \%$ \\
\hline Carol & $9 / 10$ & $90 \%$ & $5 / 5$ & $100 \%$ & $14 / 15$ & $93 \%$ \\
\hline
\end{tabular}

Source: Own developed result table.

\section{Study 1: Content Analysis}

In this study, the selected six movies are tested in the coding sheet with 15 test points in Part A and Part B.

As the result showed, the three female characters in Group A, (Hollywood mainstream action and fairy-tales films) generally fulfilled certain criteria in coding sheet Part A (20\%-70\%), and in Part $B$, the storylines of commercial films showed very little feminist concepts (20\%- $40 \%)$.

On the contrary, Group B (non-blockbuster or art house films) met more cinematic feminist criteria than Group A. From the perspective of the character (Part A), the three female characters in Group B highly reflected feminist qualities (90 to 100\%), as well as the storylines (Part B) revealed feminist concepts $(60 \%-100 \%)$.

Result in Group A: The character and the storyline of Mad Max: The Fury Road reflected 67\% of cinematic feminism. This film met 7 [Code A2, A4, A5, A6, A8, A9, A10] criteria in the character and 2 criteria [Code B2 \& B3] in the storyline. The Hunger Game reached dissatisfactory result as the film passed 6 test points in Part $A$ [Code A1, A2, A4, A6, A8, A9] and failed most of the test point [B1, B2, B4, B5] in Part B. And, Cinderella passed 4 out of 15 test points [Code A8, A10, B2, B3] and only $26 \%$ cinematic feminism found in this film's character and storyline. The female character made almost no decision and showed no intention to solve her problem; the story stereotyped her identity and image, restricted her freedom and destiny, finally made this fairy-tale the least feminist film in this study.

Result in Group B: Brooklyn fulfilled the full test points of cinematic feminism through the gender representation of the character and story structure (Part A \& Part B), and this result suggested Brooklyn as the most feminist film among the six selected films. In Carol, cinematic feminism reached $93 \%$ in performing character and story (Part A \& Part B). In the film, the female lead gave up the custody of her daughter might turn her into a victim and made this film failed test point code A7. In the film, both female characters bravely expressed their feeling and thoughts, decided their own future, and gained a better and happier life compared with the beginning of the story. Gone Girl met $87 \%$ of cinematic feminism overall as the female character presented strong determination, strategic problem-solving skill, and high ability to refuse unequal treatment, however, she remained as an angry individual that made her failed code B3 and she is unhappy at the end [failed code B2]. 
All the films Group B passed the test point B1 [the storyline and the experience of the female protagonist are possible for reality] when all the films in Group A failed the same test point. This result suggested female leads in art house and non-blockbuster films [in Group B] are expressing more feminism qualities and the storylines are more practical and possible for today society. Comparatively female leads in commercial and mainstream films [in Group A] are reflecting low feminist values in the roles and the storyline are more imaginative and unrealistic.

\section{Study 2: Film Reviews}

\section{Group A Film 1: The Hunger Games}

Analyse feminism from the perspective of character; Katniss Everdeen [Katniss] represents a modern female icon who volunteers to join The Hunger Games. In the game's training, she is low profile, low morale, passive and less aggressive. As the game goes on, her fighting ability is stimulated gradually. She presents high external masculine skills such as archery and leadership; also she expresses strong internal masculine personalities such as calmness, rational, intelligence. At the end of the game, she wins the game with her team partner, Peter. Katniss is a successful character and a capitalist product designed by Hollywood from the year 2012 until now.

From the perspective of the storyline, The Hunger Games interprets the conflict between the upper class (leader - President Snow) and lower class (leader - Katniss Everdeen). In the film, Katniss is a young girl from the lower class; who has no options and choices for her life. She takes part in the survivor game based on her nurturing nature to protect and prevent her sister from the game. In the film, she receives the instructions directly or indirectly through her male superiors on digital screens and from President Snow [Snow]; she follows the instructions and plays the game as she is told. In this film, Katniss is a well-trained subordinate and Snow represents the superior male-authority, who programmed and controlled the game.

Katniss is objectified as a target of masculine abuse; she is the target of "the games", and she is "played" by upper male society. She has low awareness towards the game' and she is unable to refuse the unequal treatments in that circumstance. In the story, she has no life's objective, she is confused and insecure, she follows instruction, accepts all the tasks, and obeys the masculine arrangements including agrees to become an entertainment icon and decorates herself with a dramatic flame dress to impress the mass audience. She keeps playing those games and following commands without expressing her real feelings and dissatisfactions. At the ending, she finally makes a rebellious but negative decision (to suicide) to challenge the authority's arrangement, to gain herself and Peter a final freedom that they both deserved. However, the compromise and agreement from the authority [Snow] are temporary and very soon his revenge turned Katniss a victim. The authority engages her to a dramatic romance with Peter even she had no interest and involves her with more games to entertain more districts' audiences in the following episodes. In the film, Katniss is just a chess that controlled by her male superior.

The storyline characterises Katniss an unconscious and submissive female, she sacrifices herself to rescue her female base family from the threats of male-domination society. The story exaggerates the masculinity escalation and punishment toward Katniss's feminist performance. In the film, she is punished and threatened on every made decision, her family and her friends suffer or die because of her decisions. She shows more intense fears and vulnerabilities in the following 
episodes - The Hunger Games: Catching Fire (2013), The Hunger Games: The Mockingjay Part I (2014), and The Hunger Games The Mockingjay Part II (2015). She receives more tasks and follows more instructions through more digital screens, she loses more friends and freedoms; she reveals more feminine fears and insecurities in the films. Her face of confused, lost, and powerless is showed when she is standing on the podium of The Hunger Games. She is forced to play this game, and she is not happy.

Katniss, the leading female in The Hunger Games shows feminist qualities through the external and physical empowerment but less internal feminist qualities, she is a role with many masculine traits but low feminist characteristics. Katniss is a powerless character that shows no ability to resist external threats and masculine exploitations. The Hunger Games is a story that describes how a woman should follow instructions, to obey male authority so could survive under them, and to have a modest but pseudo-feminine victory in a patriarchal society.

\section{Group A Film 2: Mad Max: Fury Road}

From the perspectives of the female lead, Imperator Furiosa [Furiosa] in Mad Max: Fury Road is a female fighter, and sadly, her name is only mentioned five times in the film and is not easy to recall for the viewers. Furiosa is characterised with strong masculine outlook and abilities such as fighting, driving, using weapons, saving people that usually present by a male in commercial action films. Apparently, Furiosa is considered as a significant feminist character in the film - she saves the five damsels (called as "wives" in the film) by helping them to escape from the "wasteland" that ruled by a typical masculine tyrant. She fights against the absolute authority power, ends the abuses from the masculine dictatorship, and earns herself a political victory at the end.

From the perspective of the storyline, Mad Max: Fury Road focuses on the confrontation between males and females. The story starts with a male-dominated land where females are common properties for the male leader. Young women work as "wives" to have babies for the leader; old women are providing mother milk to the male governors. This is a world that men are in charge and women are being exploited. The story treats women as masculine trophy, also abuses and sexualises woman labours, also glorified child marriage. "... Women and bodies as a sexual object, instrumentalisation, selling like a merchandise, a matter of honour, virginity check, neighborhood pressure, sexual abuses, incest, extramarital pregnancies..." (Gulser, 2016) are portrayed and praised in this film. The action is rising when Furiosa and these wives decide to escape from the land and fight against the abusive masculine authority. The story ends with the death of the male dictator, and the significant victory when Furiosa becomes a new female leader in the land.

However, Mad Max: Fury Road is a story about Max, a male drifter who assists Furiosa, makes a life-saving decision for her and eventually leads her to the redemption that she is long looking for. In the film, Furiora is brave and strong, but Max is braver and stronger. Max is a hyper-masculine icon in this film as he contributes huge efforts to help Furiosa and her escape plan. The film actively praises his crisis management skills, team spirit, decision-making power, leadership, and determinations. He is the silent hero that plays up the masculine supremacy in this film. Not denying, Furiosa is showing various masculine traits such as leadership, athletic, assertive, strategic, willing to take a risk, defending own beliefs, operating a heavy machine, vehicle, and weapons. However, these traits are comparatively faded and punished at the end of the film - 
when all Furiosa's decisions are all wrong and the escape plan is rearranged by Max. He saved Furiora and made peace. Finally, women are standing on the podium to declare victory because Max gave away the position and he chose to leave. Mad Max: Fury Road starts with Max's narrative indicating - this is his story. He is the backstage hero that able to solve all women problems and free them from suffers. The film shows a rebel escape plan that started by a group of female but completed by a man, who is actually the real protagonist of the film.

\section{Group A Film 3: Cinderella}

The character, Cinderella presents with many traditional and stereotypes feminine characteristics such as submissive, indecisive, no intention to make a change of life; also with some positive personalities such as tolerance, obedience, understanding, loyalty, acceptance, and forgiveness. These feminine characteristics lead her to gain unrealistic rewards - an effortless rescue and a royal marriage. Her happiness in the film is highly contrasting with her dominant and strategic stepmother, who is awfully characterised as dark, ugly, and evil femme-fatale in the story. From the designed characters, this film segregates women into two typical stereotypes - age and outlook; and objectifies women as a source of problems by emphasizing many conflicts in the feminine world. The story of Cinderella highlights traditional connotation of flaw relationship in oldfashioned feminine society by strongly emphasizing domestic conflicts, feminine jealousy, and family cruelness. This story also sets a symbolic metaphor of feminine deterioration in that old society as "women created conflicts, and men solved it".

In the storyline, the "midnight" plot not merely proposes the restriction of freedom towards females; it also suggests females to use inferior tricks for increasing self-desirable value in masculinity society, which none of these reflects any modern feminism values. The midnight clock sadly brings out the truth: the prince has very limited realistic information about Cinderella. He has no idea about her name, where she lives, who she is, or how to find her. Cinderella is just an attractive face, a pretty dress, and a left slipper for the prince and for everyone in the palace. Her identity contains minimum attention than her appearance; she is just "the girl" for the prince, the king, and the other royal males. In this film, male society gives more credits toward females' image and gives little recognitions toward females' identity.

The left slipper of Cinderella symbolises the beauty standard and female representations in supreme masculine society - young, pretty, and no personal identity. The lost and found slipper plot in the story exaggerates the admiration and desperation of general females toward upper class. The left slipper in this story is not just a signifier for highlighting females' physical and psychological mutilation but is clearly reflecting the twisted masculine benchmark towards women's body and appearance.

"Have courage and be kind" - the tagline of the film is famously repeated without much realistic implications and applications of the "courage". Cinderella is still the imprisoned victim, who loves singing [to solve all the problems], who has no human friends, no social life, and no intentions to fight against the domestic violence or to change any unfair situations. She is a passive character that accepts feminine subordination, exploitation, and domesticity. She silently shows high interest towards royal ball party [or royal superiority]; she hopelessly and positively connects the royal male [that she only met twice] with her life's true love; she blindly follows a wealthy stranger who doesn't know her name just to get her family complications solved effortlessly. Cinderella obviously is not a portrait of feminism in Disney or in today's modern cinemas. 


\section{Comparison of Group A Films}

To analyse commercial films' female characters from the perspective of feminism, Katniss and Furiosa are showing with various masculine traits; Cinderella is characterised with traditional femininity personalities. The three lead females in films Group A are stereotypically portrayed as survivors from lower class society when males in these films are holding higher power to decide women's future and life. The films' stories emphasized on male superiority through actors' achievements, status, and decisions; and highlighted female inferiority through actresses' insecurity, hopelessness, and domestic conflicts. Katniss presents out women's fears and anxieties towards upper patriarchal rules; Furiosa shows insufficient abilities and feminine powerless to overthrow male-dictatorship; Cinderella demonstrates exaggerated females' veneration towards wealthy male-authority.

Katniss, Furiosa, and Cinderella are portrayed similarly - to win the game, to live in a peaceful world, to be generally kind, and they go for it. "Nevertheless, the representation of these powerdefined women brings with it a stigma that calls into question their work success. For the most part, they are negative female characters: ambitious, unscrupulous, resentful, vengeful, despotic, strong and implacable. Their professional success is frequently belittled by associating their position of power with other male characters (husband, father, etc.)" (Lacalle \& Góm ez, 2016). In storylines, they are deprived of choices, freedoms, problem-solving abilities and decision-making rights. In these films, male supremacy is being promoted when feminism is gradually demoted. Female characters are given certain feminist qualities to refine the sovereign masculinity in mass cinemas, and these qualities are under the shadow of male-dominated storylines. The selected female-leading films in Group A are carrying superficial feminist characters with the hidden agenda of promoting implicit masculinity connotations in storylines.

\section{Group B Film 1: Gone Girl}

The lead female character, Amy Dunne [Amy] portrays an American wife, who revenges her husband's betrayal by faking herself as a victim of domestic violence and a target of murder. From the analysis of the lead character [not from the analysis of psychology], Amy characterises with masculine traits such as analytical, independent, dominant, forceful, assertive, decisive, competitive, violent, strategic. She refuses to be a victim from her failed marriage and chose to incharge for the unpleasant circumstance. In the story, she fights back her husband's betrayal tactically and finally makes him the victim of their marriage instead of herself.

Amy is a character and she understands how gender bias could work well in the modern conventional society of America [men love cool girls, society loves traditional women, women are perceived as weak, kind, and innocence, men are strong, violence and dominance]. She smartly uses the media as a spotlight to obtain public attention and huge social acceptance on her family case by setting up typical images and identities of husband and wife based on the popular expectations of society. By using the gender discriminations of American society, Amy develops few typecast characters and stories to obtain quick absorption of gender-biased from media and society. From Amy's plan, the labels of "irresponsible, violent husband" and "kind, tolerant wife" have gained her general agreement, sympathy, and admiration. Her scheme of gender misrepresentations has finally glorified herself with a big win to get her husband punished by the biased mass audience, and to get herself to become a new American sweetheart. 
Analyse feminism from the perspective of the storyline, the structure of Gone Girl gives a signifier of contemporary bias perception toward gender identities. The film's plot also reminds viewers that gender misrepresentations of "good-girl and bad-boy" that practicing in everyday society. Compare with old-fashioned cinemas, this film uniquely presents its cinematic feminism and teases gender stereotypes through a psychoanalytical female antagonist, a twisted plot of male victim and female villain. In Gone Girl, Amy could be "the crazy nightmarish woman" for misogynists but "the self-determination cynical woman" for feminists. She is an extreme character, who uses extreme solution, in an extreme situation. She makes an effort to change her passive position by developing a revenge plan. In this study, her plan and intention do not fulfill the ethical standard of feminism. However, her initiatives of making changes, her courage to fight unfair situations are the fundamental criteria in this study.

\section{Group B Film 2: Brooklyn}

From the perspective of the character, Brooklyn illustrates an Irish woman, Ellis Lacey [Ellis] and her growing process from grief to delightful by starting a new life in Brooklyn. Her migrant decision is not turning her into a victim but making her a better and happier person. From a young, untactful, confused, and timid girl from Ireland, Ellis transforms to a confident, independent, assertive woman in Brooklyn. She actively faces the contradictions of double life and double love in between traditional society in Ireland and modern country in Brooklyn.

The storyline defines cinematic feminism by describing how a young immigrant female confronts the traditional pressure, guiltiness, and fear; how feminine persistence solves the complexity of emotions and difficulties of choices that usually appear in conventional society. The narrative of Ellis's double romance suggests an event to turn feminine confusion to feminist affirmation; the threat from Ellis's former employer (Ms. Kelly) symbolises the oppression from old-fashioned society. These plots strategically counteract Ellis's confusion, develop her honestly, and accelerate her determination of getting out from unequal treatment and conventional rigidness. In the final plot, Ellis back and leaves Ireland again, with her new self-identification, and this confidence allows her to advise a new Irish immigrant about living information of single women in a foreign country. Her advice reflects her mental maturity, vision clarity and feminist qualities that gained from her previous bitter experiences. These self-developed experiences have her reconstructed from a vulnerable young girl to a confident grown woman that enabled her to pay feminist strength forward.

\section{Group B Film 3: Carol}

Carol, a movie about two women: Carol Aird [Carol] and Therese Belivet [Theresa] that are from different backgrounds, places, and ages; how they met and found romance, courage, and identity from each other in the city of New York, 1950. In the film, the society is still highly conservative and judgmental; the two female characters break free from the male-order domination, challenge the barrier of traditional structure, and reach a revolutionary change in conventional female society.

From the perspective of female roles, the first leading character, Carol is a wealthy yet longsuffering housewife with a daughter. She uses huge efforts to take a stand against her heterosexual marriage and to defend her own sexual orientation. She chooses to face the barriers and open embarrassments from her husband towards her lesbianism. She makes difficult 
decisions and gives up custody of her daughter. Interestingly, compared with the typical oldfashioned mother roles of Hollywood, who would sacrifice everything to protect her child, Carol's decision is marked as an innovation move and a calm action to protect her child from the harm of family battle. From Carol's decision, she switches her position of a failed marriage victim to a decision-maker.

The second female character in the film, Therese is a submissive, timid, and untactful photographer at the beginning of the movies. However, Theresa soon finds her realisation and self-actualisation that inspired by Carol. Together with Carol, Theresa finds enthusiasm and motivation of her career and life. Her later maturity and confidence upgrade her to be the person who refines the happiness of two women at the end of the story.

The storyline of Carol not objectified homosexual with a convention tragedy ending as common LGBT films before. In this film, both Carol and Therese present decisive females that brave to defend their future. The story writes Carol with traits of masculinity and femininity by portraying her as a wise middle-aged mother and a persistence individual; and the story converts Therese from a submissive and introvert young girl to an independent woman that finally found her personal value, social position, and self-affirmation in the rigid society of 1950 .

Carol is a story about how two women meet, encourage and inspire each other to be a better individual by going through social difficulties together. Carol is a homosexual film that generously allows the female protagonists to express delicate and fine feminist qualities without many abusive punishments and social judgments toward feminine decisions.

\section{Comparison of Group B Films}

From the perspective of storylines, Brooklyn, Gone Girl and Carol show the feminist determinations in conformist, stereotypical and traditional societies. These films present implicit feminist abilities by concentrating on the plots that allowing feminist opinions, emotions, and decisions.

The stories of the selected three films in Group B are portraying females without overstated external costumes and impressive images, but they are sharing similar internal traits - they show clear vision and objectives; they are allowed to express their feelings and thoughts; they decide and choose what they want. These roles are able to reach their targeted destination with their own efforts and assertive actions without much masculine helps.

In the perspective of the character, the lead characters Ellis, Amy, and Carol are an immigrant, a wife, and a divorced lesbian respectively. These females might not be the perfectly flawless women but they are characterised with exclusive internal feminist qualities. Ellis makes her biggest effort to explore the new world from a conventional Irish society; Amy refuses to be a marriage's victim by smartly take advantages of a gender bias society; Carol defends her selfworth and escapes from an oppressed society and restrained rituals. In Group B, characters are significantly designed to subvert the traditional female roles in film productions; stories are specifically developed to connect the possible reality.

Females in these films symbolise everyday women with realistic situations. The characters are closely connected to reality and contemporary world. They face daily difficulties and patriarchal pressures; they are depressed, frustrated and outcast. At the same time, they positively confront 
the existing challenges and plays up feminist individualism. The female characters in Group B are not loud as the female heroes or stunning princess in Group A, whose have completed with masculine physical or external beauty; however, female characters in Group B are realistic, balanced, unique, up-close and personal. In Group A, female characters are: a profit-making empowered female in The Hunger Games, a hyper-masculine rescuer in Mad Max: The Fury Road, and a damsel in distress in Cinderella. In Group B, female leads redefined cinematic feminism to an innovated equilibrium through characters presentation of moderate [Brooklyn], sensible [Carol] but solid [Gone Girl], and it convinces viewers better than pseudo-feminism that popularly happened in blockbuster productions.

\section{$6 \quad$ Finding}

The female portrayals in Hollywood mainstream cinemas are accentuating on unrealistic and ostentatious images, which are either extremely masculine or feminine. The stories promote the cinematic masculinity with purposive involvements of female hero or princess, praise indirectly for patriarchal authority, and aim for financial responses from mass audiences.

On the contrary, the female portrayals in non-blockbuster art house films are physically and emotionally stable; they are connecting to resilient roles with social reality and writing out from the domination of masculine societies. The stories unfold the details of featured feminist qualities and transferring the subtle values of feminism to resonate the specific spectators.

\section{Research Outcomes}

There are 4 core outcomes in this study. The developed objectives and hypotheses are answered and proved through the four outcomes:

(1) The mainstream blockbuster films demonstrate feminism through characters only; the nonblockbuster or art house films express feminism through both characters and storylines.

(2) The female lead characters in mainstream blockbuster films present external feminism through physical empowerment and the roles are almost a counterpart of man (which we may argue still functioning under male's framework); the female lead characters in nonblockbuster or art house films assemble internal feminism through expressing of behavioural balance and emotional independence.

(3) The storylines of mainstream blockbuster films establish more plots to promote and praise for patriarchal rules and governances; the storylines of non-blockbuster or art house films concentrate on females' story without much focuses on male domination.

(4) Mainstream blockbuster films structure female characters as the irrepressible icon and the stories are commercially fictional, the cinematic feminism is hardly applied to reality nonblockbuster or art house films accumulate female characters as resilient and witty individuals with everyday problems, the cinematic feminism is possible for reality.

(5) Cinematic feminism is embodied non-blockbuster or art house productions progressively and actively compare with mainstream blockbuster productions. 


\section{Objectives \& Hypotheses}

Objective 1, 2 and 3 [to explore the cinematic feminism in mainstream blockbuster films and nonblockbuster art house films; to compare feminist qualities through representations of characters and interpretations of storylines; and to justify the reflections of reality in between mainstream blockbuster films and non-blockbuster art house films], are completed with data analysis in study 1 and film reviews in study 2 .

Objective 1 is completed by study 1 ; coding sheet that documented the developments of gender representations in characters and in stories of the six female-leading films. Objective 1 constructed outcome 1 and outcome 2 as abovementioned.

Objective 2 is completed by study 2; film review that analysed and compared the reflections of feminist qualities in characters and in the storyline for the selected films. Objective 2 generated outcome 1, outcome 2, and outcome 3 as abovementioned.

Objective 3 is completed by study 2; film review that justified the reflection and connection of reality in mainstream popular and non-blockbuster art house female-leading films. This objective formulated outcome 4 as abovementioned.

Hypothesis 1 [Mainstream blockbuster films and non-blockbuster art house films will reveal different interpretations of feminism] is answered with the abovementioned outcome 1 and outcome 2. Hypothesis 1 is also proven through study 1 in data analyse for the overall interpretation of cinematic feminism.

Hypothesis 2 [Mainstream blockbuster films emphasize on an unrealistic character such as heroin or princess by a male-manipulated and patriarchal story; comparatively, non-blockbuster art house films emphasize on an insightful character with a realistic story] is proven with outcome 3 and outcome 4 . Hypothesis 2 is also enhanced through study 2 in film reviews for the and discussion and comparison of characters and storylines.

\section{Theoretical Application and Review}

\section{Types of Feminism}

From the result of this study, The Hunger Games and Mad Max: The Fury Road are intended to follow the liberal feminism by creating female superheroes that live in a world that ruled by men; Cinderella has projected the fundamental concept of cultural feminism. However, these films expressing extreme masculinity/femininity and highlighting traditional masculine/feminine behaviours that are not literally supporting by the fundamentals of liberal feminism or cultural feminism. In this paper and the six selected films, female characters are portrayed with various types of cinematic feminism. In this paper, three different types of cinematic feminism are found and coded as:

Typecast Feminism - female characters are designed with a big amount of traditional feminine characteristic and advocating fiercely of conventional femininities through her stereotyped image, behaviours, and thinking. Female characters in commercial romances and popular Disney princesses films are promoting females' stereotyped external images with long hair, sing and talk to animals, domestic tasks, pretty faces, imprisoned and cursed; and internal representations as a silent victim of dominant force and to get love and married as an escape to all problems. Typecast 
feminist characters encourage global children in their early childhood to adapt to extreme and twisted femininity by focusing external beauty more than internal ability; segregating women into age and outlook discriminations, and emphasizing many conflicts in feminine world through highly repetitive and consistent characters and storyline such as Cinderella in Cinderella (2015), Maleficent in Maleficent (2014), Ravenna in Snow White and The Huntsman (2012). Typecast feminist characters not only set distorted gender expectations in popular fairy-tales and broadcasted the negative standards of feminism widely to international children and their early childhood; typecast feminist characters also happen in popular comedy romances and chick flicks that targeted to young women. Female leads in comedy romance are usually clumsy but kind, unwise but passionate, troublesome but optimistic. And these typecast characteristics will finally be rewarded with a good romance. For instance, females in "...Bridget Jones's Diary, How to Lose a Guy in 10 Days, The Devil Wears Prada, or Confessions of a Shopaholic feature an early undercurrent of uneasiness or discomfort with post-feminist ways of living. Bridget's cry of pain when waxing, or her rehearsing of appropriate conversation topics ("isn't it terrible about Chechnya?" she repeats while hoovering her flat in a vest and knickers) during her own predate montage hint at her failure to successfully inhabit the post-feminist "poise" she so desperately craves. Meanwhile, in Shopaholic, the joy of shopping is seriously undercut by Rebecca's mounting debt. Similarly, Andy discovers that the path to being a journalist is less than glamorous in The Devil Wears Prada (Thouaille, 2018). The concept of typecast feminism is broadly intensified and delivered to female children and teenagers through mainstream fairy-tales, comedy romances, and chick flicks.

Masculine feminism - indicates female characters that improved with innovation gender representations from girlhood/womanhood to knighthood and portrayed as superheroes or fighters. Female characters in blockbuster films and action films are designed as prevalence and flourish female icons with masculinised abilities but living in a patriarchal society. These films include Katniss Evergreen in The Hunger Games (2012), Imperator Furiosa in Mad Max: The Fury Road (2015), Black Widow in Avengers (2012), Diana in Wonder Women (2017), Okoye In Black Panther (2018), Carol Danvers in Captain Marvel (2019), These icons are mostly created to satisfy the market value and capitalist requirements or just to attract more female audiences [or male audiences]. These masculine feminist characters are usually packaged with exaggerated outfit and image to highlight female figures; objectified as female heroes with a sinewy body, excessive physical performance and perfect health condition to make equivalence portrayal as male characters. "Either women have to act tough or they are sexualized. This goes to show that women have not achieved much progress as they are perpetuating gender stereotypes in the action films" (UKEssays, 2018). By evolving females with masculine empowerment and physical aggressiveness, these stories intent to present shallow and misleading feminism, and turn unauthenticated feminist characters recklessly into sensational cinemas for commercial purposes with the fancy feminism in movies' posters or in advertising trailers. However, decorate female characters with manliness criteria, changing female external representation, making female characters look alike men superheroes could not upgrade cinematic feminism, it is just another rhetorical action that played by the commercial film industry.

Moderate Feminism - Females are portraying with a higher quality of personalities with internal representations without much deteriorations in the image and in physical. Female characters are allowed to show authentic and natural reactions without much patriarchal pressure. The female 
character's identity and image are recognisable and agreeable. The role is not objectified her into a sex object and not masculinising her. She is enjoying proper freedom for decisions and expressing her feeling and thinking. She is able to make choices, accept her flaws, solve her problems, refuse the external threats, she fights for her better life and becoming a happier person. Moderate feminism emphasizes on choice that women able to make, also it reflects the discourse of post-feminism: "a set of ideologies, strategies, and practices that marshal liberal feminist discourses such as freedom, choice, and independence, and incorporate them into a wide array of media, merchandising, and consumer participation" (Banet-Weiser, 2018). Following the ideology, female leads are not only allowed to make choices, also are encouraged to express emotions and make changes. "If post-feminist culture calls forth a subject incited to work on her character and psychic dispositions, then it also works by attempting to shape what and how women are enabled to feel and how their emotional states should be presented" (Gill, 2017). Moderate feminism films consent the post-feminism to develop gradually through the subtle feminist expressions of the lead characters and the stories such as Ellies Lacey in Brooklyn (2015), Carol and Theresa in Carol (2015), Amy Dunne in Gone Girl (2014), Ma in Room (2015), Joy in Joy (2015), Kate Mercer in 45 Years (2015).

\section{Visual Pleasure and Cinema Narrative}

In Laura Mulvey's Visual pleasure and cinema narrative, "the "male gaze" invokes the sexual politics of the gaze and suggests a sexualised way of looking that empowers men and objectifies women. In the male gaze, woman is visually positioned as an "object" of heterosexual male desire. Her feelings, thoughts and her own sexual drives are less important than her being "framed" by male desire. Visual media that respond to masculine voyeurism tends to sexualise women for a male viewer. As Mulvey wrote, women are characterised by their "to-be-looked-atness" in cinema. Woman is "spectacle", and man is "the bearer of the look" (Simmons, 2016).

Following the idea, the gaze and could be categorised to two levels: The first level - female characters are the objects "to-be-looked-at-ness". Male spectators are the subject to look and pleasure [sexually] gained from gazing on female characters. The second level - female characters are still the objects "to-be-looked-at-ness", maybe not sexually but more to shift and stimulate male spectators' behaviours to be more voyeuristic or narcissistic.

In this study, the three mainstream blockbuster female characters in group A, passed level 1 but remained at level 2. Cinderella, Katniss, and Furiosa are the targets of "to-be-looked-at-ness", although they are not the targets of sexual voyeuristic scopophilia for male viewers, they are still the victims of masculine narcissistic scopophilia. These female characters are designed mostly to satisfy male viewers pleasure to witness males [in the films] are in charge of women's life and women are in threats. "Archetypes portrayed in movies today tend to gravitate towards the new action heroine where the heroines depicted are not threatening to the fantasies of heterosexual males who made up most of the audience, the action genre as a typically male genre and the male gaze" (Stasia, 2004). Following the ideology, Cinderella, Katniss and Furiosa are the mainstream characters that are not beyond the label of "to-be-looked-at-ness". Group A mainstream films that selected in this study are not reaching the benchmarks of cinematic feminism that promoted by Laura Mulvey. These films stereotyped female characters and intended to gain males' pleasure and to satisfy masculine narcissistic in popular cinemas. 


\section{Conclusion}

A film with a female-lead does not mean it is a feminist film. Mainstream female-leading films are produced with a high budget, to meet the record of the box office by constructing the concept of mainstream cinematic feminism that commonly accepted and praised in top-grossing theatres. "Male dominance and patriarchy are a widespread social nature on the world along with the capitalism that is an exploitation tool of women's domestic labour and forming the basis of capitalist societies" (Gulser, 2016). Mainstream and male dominant stories created high market value female characters and turned them into fictional female heroes with excessive masculinity, or dreamy princesses images with extravagant femininity to establish superficial and non-realistic feminism in contemporary cinemas. The mainstream cinematic feminism highlights popular characters with shallow external feminist designations without much solid relevance with internal qualities. It could be simply a combination of typecast feminism and masculine feminism that reflected in a mainstream female-leading blockbuster film.

Female protagonists in mainstream cinematic feminism are portrayed as popular female models that virtually walk between masculinity authority and femininity limitations. Alternatively, popular feminists are adapting to unrealistic masculine identities or stereotypical victims to gain the pleasure of mass audiences. Under these circumstances, female leads that are labelled as "feminists" in popular screens; they are at the same time, demonstrating feminism with a negative connotation and putting an old-fashioned corset to the modern feminism cinemas.

This paper studies the concepts of feminism in modern cinemas, involving series of interactions between ideas and actions, content and context, perceptions and attitudes of different filmmakers and viewers. "In fact, of course, people's subjective attitudes and ideas about everything will fluctuate continually, and hence it is impossible to stabilize attitudes by coercion; certainly it would be immoral and aggressive against other people's rights to try" (Pavel \& Mark, 2017). It is not easy to amend the stereotyped identity of female leads in mainstream stories; or to redefine the omissive and subjective female characteristics in blockbuster films; however it is possible to develop an effective measurement to justify cinematic feminism standard in popular cinemas and avoid more misleading concepts of feminism deliver from film productions to global viewers. This study outlined a coding sheet to generate the overall feminism qualities of female leads, to make feminism in films could be witnessed and documented.

This paper argues that the cinematic feminism is not to transfer the gender identity of women, or make women accomplish men's mission to prove females' masculinity, or promote the masculine feminism by demoting femininity for only financial gains in the film industry. Also, cinematic feminism is not to isolate young women in a fairy-tales world that she could only submits herself to the 'fate' of life; or to wait for a sudden appearance of a prince, and believe a mystical power of life-saving's true love kiss could solve all her problems as explained in typecast feminism. Neither masculinising female body and manlinessing her gender identity nor traditionalised her femininity is the core idea of feminism in this study. It is about self-determination. Cinematic feminism is about to accept women existent criteria and resolve the gender doubts by providing equal opportunities to choose, express, change and decide in female-leading stories. When the time female characters are not being repeatedly punished, threaten, forced because of the choices and decisions that she made; female stories are not being habitually arranged with conventional structures and patriarchal rules to obey; female-driven films are happily ended with presentations 
of freedom to choose, ability to make changes, and courage to refuse unequal treatment to get personal preferred life - that is the time for global audience to celebrate the on-screen feminism in popular cinemas.

\section{References}

\section{Book List / Journal List:}

Banet-Weiser, Sarah. (2018). Postfeminism and Popular Feminism. Feminist Media Histories 4 (2):152156. doi:10.1525/fmh.2018.4.2.152.

Chaudhuri, Shohini. (2006). Feminist Film Theorists: Laura Mulvey, Kaja Silverman, Teresa De Lauretta, Barbara Creed. US: Routledge Taylor \& Francis Group. https://doi.org/10.4324/9780203357026

Gill, Rosalind. 2017. The Affective, Cultural and Psychic Life of Postfeminism: A Postfeminist Sensibility 10 Years On. European Journal of Cultural Studies 20 (6): 606-626. doi: 10.1177/1367549417733003.

Gulser Oztunali Kayir. (2016). Sociological Regard to Child Mothers Drama in Turkey. International Journal of Social Sciences. Vol. V(2), pp. 73-91. doi: 10.20472/SS2016.5.2.005.

Karlyn, Kathleen Rowe. (2011). Unruly Girls, Unrepentant Mothers: Redefining Feminism on Screen. Austin, TX: University of Texas Press.

Lacalle Charo \& Gómez Beatriz. (2016). The Representation of Workingwomen in Spanish Television Fiction. Media Education Journal. doi: 10.3916/C47-2016-06.

Lassale, Mick (2012). The Beauty of the Real: What Hollywood Can Learn from Contemporary French Actress. Stanford, CA: Stanford General Book.

Thouaille, Marie-Alix. (2018). Post-feminism At An Impasse? The Woman Author Heroine In Postrecessionary American Film. Feminist Media Studies. doi:10.1080/14680777.2018.1546203.

Pavel Slutskiy \& Mark Hamilton. (2017). Correlates of Colorism: Freedom of Speech and Discriminatory Advertising in Thailand. International Journal of Social Sciences. Vol. VI(2), pp. 63-76. doi: 10.20472/SS2017.6.2.005.

Projanskly, Sarah. (2014). Spectacular Girls: Media Fascination and Celebrity Culture. New York: New York University Press. https://doi.org/10.18574/nyu/9780814770214.001.0001

Stasia Cristina Lucia. (2004). 'Wham! Bam! Thank You Ma'am!': The New Public/Private Female Action Hero. In: Gillis S., Howie G., Munford R. (eds). Third Wave Feminism. Palgrave Macmillan, London. https://doi.org/10.1057/9780230523173_15

Syed, Jawad \& Murray, Peter A.. (2008). A Cultural Feminist Approach Towards Managing Diversity In Top Management Teams. Equal Opportunities International. Vol. 27, Issue: 5, pp.413-432. https://doi.org/10.1108/02610150810882288

Thornham, Sue. (2007). Women, Feminism \& Media. Edinburg: Edinburgh University Press.

Tong, Rosemaria. (2009). Feminist Thought: A More Comprehensive Introduction. Philadelphia, PA: Westview Press.

\section{Electronic sources:}

Box Office Mojo. (2013). Available from http://www.boxofficemojo.com/alltime/adjusted. htm. [Accessed 12 March 2019].

"Bechdel Test Movie List" Stats Bechdel Test Movie List. Available: https://bechdeltest.com/. [Accessed 18 April 2019]. 
Simmons Andy. (2016). Explainer: what does the 'male gaze' mean, and what about a female gaze? Available: http://theconversation.com/explainer-what-does-the-male-gaze-mean-and-what-about-a-femalegaze-52486. [Accessed 25 March 2019].

UKEssays. (2018). The Representation Of Women Film Studies Essay. Available from: https://www.ukessays.com/essays/film-studies/the-representation-of-women-film-studies-essay. php?vref=1.

[Accessed 10 April 2019].

\section{Film List}

Brooklyn. (2015). Directed by John Crowley [Film]. Canada\& United Kingdom: BBC Films (UK), Telefilm Canada (Canada), HanWay Films (UK), \& Wildgaze Films (UK).

Cinderella. (2015). Directed by Kenneth Branagh [Film]. USA: The Walt Disney Company \& Kinberg Genre \& Allison Shearmur Productions.

Carol. (2015). Directed by Todd Haynes [Film]. UK \& USA: Number 9 Films (UK), Killer Films (USA) \& Film4 Productions (UK).

Gone Girl. (2014). Directed by David Fincher [Film]. USA: Regency Enterprises \& TSG Entertainment.

Mad Max: Fury Road. (2015). Directed by George Miller [Film]. Australia, USA: Warner Bros. Pictures (USA), Village Roadshow Pictures (Australia-USA), Kennedy Miller Mitchell (Australia) \& RatPac-Dune Entertainment (USA).

Pacific Rim. (2013). Directed by Guillermo del Toro [Film]. USA: Legendary Pictures \& Warner Bros. Pictures \& Universal Pictures.

The Hunger Games. (2012). Directed by Gary Ross [Film]. USA: Lionsgate Films.

The Hunger Games: Mockingjay Part 1. (2014). Directed by Francis Lawrence [Film]. USA: Babelsberg Film Studio \& Color Force.

The Hunger Games: Mockingjay Part 2. (2015). Directed by Francis Lawrence [Film]. USA: Babelsberg Film Studio \& Color Force.

Captain Marvel. (2019). Directed by Anna Boden, Ryan Fleck [Film]. USA: Marvel Studios.

Tomb Raider. (2018). Directed by Roar Uthaug [Film]. USA \& UK \& Japan: Metro-Goldwyn-Mayer Studios, Warner Bros. Pictures, GK Films (UK), Square Enix (Japan).

Ocean's 8. (2018). Directed by Gary Ross [Film]. USA: Warner Bros. Pictures, Village Roadshow Pictures, Smokehouse Pictures \& Lager Than Life Productions.

Wonder Woman. (2017). Directed by Patty Jenkins [Film]. USA \& China: DC Entertainment (USA), RatPac Entertainment (USA), Atlas Entertainment (USA), Cruel and Unusual Films (USA), Tencent Pictures (China) \& Wanda Pictures (China).

Lucy. (2014). Directed by Luc Besson [Film]. France: EuropaCorp Distribution, TF1 Films Production Canal+, Ciné+ \& TF1.

Divergent. (2014). Directed by Neil Burger [Film]. USA: Red Wagon Entertainment \& Summit Entertainment.

Destroyer. (2018). Directed by Karyn Kusama [Film]. USA: 30West, Automatik Entertainment, Annapurna Pictures.

Eighth Grade. (2018). Directed by Bo Burnham [Film]. USA: A24 \& IAC Film \& Scott Rudin Productions. 
Room. (2015). Directed by Lenny Abrahamson [Film]. Canada, USA, UK \& Ireland: FilmNation Entertainment (USA), Telefilm Canada (Canada), Film4 (UK), Fís Éireann/Screen Ireland (Ireland), Ontario Media Development Corporation (Canada), Element Pictures (Ireland), No Trace Camping (Canada-USA) \& Duperele Films (UK).

45 Years. (2015). Directed by Andrew Haigh [Film]. UK: Film4 Productions, British Film Institute, Creative England \& The Bureau.

Joy. (2015). Directed by David O. Russell [Film]. USA: $20^{\text {th }}$ Century Fox, Davis Entertainment Company, Annapurna Pictures \& TSG Entertainment.

Still Alice. (2014). Directed by Richard Glatzer \& Wash Westmoreland [Film]. USA \& UK: Killer Films, Lutzus-Brown, BSM Studio, Big Indie Pictures, Shriver Films.

Blue Jasmine. (2013). Directed by Woody Allen [Film]. USA: Gravier Productions \& Perdido Production. 